\title{
HUBUNGAN ANTARA EKSPRESI CYCLOOXYGENASE-2 DAN GAMBARAN KLINIKOPATOLOGIKAL DARI KANKER KOLOREKTAL DI RSUP SANGLAH
}

\author{
Gede Budhi Setiawan*, Wayan Sudarsa, I.B. Tjakra Wibawa Manuaba \\ Subbagian Bedah Onkologi, Bagian Ilmu Bedah, Fakultas Kedokteran, Universitas Udayana, RSUP Sanglah, \\ Denpasar. "Korespondensi: dhiwans@ hotmail.com
}

\begin{abstract}
ABSTRAK
Tujuan: untuk menyelidiki hubungan dari ekspresi cyclooxygenase-2 (COX-2) dengan gambaran klinikopatologikal pasien dengan kanker kolorektal (CRC). Metode: ekspresi COX-2 diperiksa mengunakan imunohistokimia pada 46 pasien dengan kanker kolorektal, di Rumah Sakit Sanglah Denpasar, antara bulan September 2004 dan November 2005. Dilakukan analisis hubungan ekspresi COX-2 dengan gambaran klinikopatologikal. Hasil: pewarnaan COX-2 terekspresi pada 91,3\% sampel. Ekspresi COX-2 sebesar 94,6\%, dan 100\% pada stadium III dan IV CRC, dan berkorelasi positif dengan tahap TNM dari CRC (Spearman's rho 0,846, p<0,05). Ekspresi COX-2 100\% pada CRC yang berdiferensiasi buruk dan berkorelasi positif (Spearman's rho 0,456, $\mathrm{p}<0,05$ ). Tidak ada korelasi antara ekspresi COX-2 dan usia pasien, jenis kelamin, lokasi tumor, dan jenis histopatologi CRC ( $>0,05$ ). Simpulan: ekspresi COX-2 diregulasi pada CRC, dan berhubungan dengan TNM, dan diferensiasi. Hasil ini lebih mendukung bukti bahwa COX-2 mungkin terlibat dalam karsinogenesis dari CRC.
\end{abstract}

Kata kunci: ekspresi cyclooxygenase-2, kanker kolorektal, stadium TNM, diferensiasi.

\section{THE CORRELATIONS BETWEEN CYCLOOXYGENASE-2 EXPRESSION AND CLINICOPATHOLOGICAL FEATURES OF COLORECTAL CANCER IN SANGLAH HOSPITAL DENPASAR}

\section{Gede Budhi Setiawan, Wayan Sudarsa, I.B. Tjakra Wibawa Manuaba}

Surgical Oncology Subdivision, Department of Surgery, School of Medicine, Udayana University, Sanglah Hospital, Denpasar, Bali.

\begin{abstract}
Objective: to investigate the associations of cyclooxygenase-2 (COX-2) expression with clinicopathological features patients with colorectal cancer (CRC). Methods: the expression of COX2 was examined by immunohistochemistry in 46 patients with colorectal cancer, in Sanglah Hospital, Denpasar, between September 2004 and November 2005. The associations of COX-2 expression with clinicopathological features were analyzed. Results: the COX-2 staining were remarkably expressed in $91.3 \%$ of samples. The expressions of COX-2 were $94.6 \%$, and $100 \%$ in stage III and IV CRC, and positively related to TNM stage of CRC (Spearman's rho 0.846, $\mathrm{p}<0.05$ ). COX-2 expressions were $100 \%$ in poorly differentiated CRC and related positively (Spearman's rho $0.456, \mathrm{p}<0.05$ ). There was no correlation between COX-2 expression and patient age, sex, tumor location, and histopathological type of CRC ( $p>0.05$ ). Conclusion: the expression of COX-2 was upregulated in CRC, and related to TNM stage, and differentiation. These results further support the evidence that COX-2 may be involved in carcinogenesis of CRC.
\end{abstract}

Keywords: cyclooxygenase-2 expression, colorectal cancer, TNM stage, differentiation. 


\section{PENDAHULUAN}

Kunci utama keberhasilan penanganan colorectal cancer (CRC) adalah ditemukannya CRC pada stadium dini sehingga memudahkan dilakukan terapi bedah kuratif. ${ }^{1}$ Walaupun pembedahan, kemoterapi dan radioterapi berkembang dengan pesat, angka kekambuhan CRC masih tetap tinggi. ${ }^{2}$ Sekitar 40-50\% penderita CRC mengalami kekambuhan dalam 3 tahun pertama setelah pembedahan dan meninggal akibat metastasis, dengan pembedahan kuratif ditambah kemoterapi postoperatif, angka kekambuhan menurun menjadi 23\%. ${ }^{3}$ Diduga terdapat faktor lain yang mempengaruhi tingginya angka kekambuhan tersebut.

Karsinogenesis CRC ditandai dengan pertambahan ukuran, derajat displasia dan potensi invasif suatu keganasan. Gambaran atau perubahan-perubahan tersebut dipakai sebagai parameter untuk memprediksi rekurensi, progresifitas, prognosis dan keberhasilan terapi CRC. ${ }^{4}$ Karsinogenesis CRC merupakan suatu sequence yang berkembang dari suatu adenoma dan berakhir dengan terbentuknya carcinoma sehingga disebut "adenoma-carcinoma sequence". Sequence ini berjalan bervariasi bahkan sampai puluhan tahun. ${ }^{5}$ Ada 3 pathway yang berperan dalam karsinogenesis yaitu angiogenesis, apoptosis dan metastasis. ${ }^{6}$ Studi eksperimental menunjukkan peranan cyclooksigenase dalam mekanisme dan pathway yang berhubungan dengan karsinogenesis. ${ }^{4,7,8}$

Ekspresi COX-2 dalam CRC muncul melalui berbagai macam mekanisme yang berbeda dan melibatkan signaling pathways yang berbeda-beda. Beberapa celular markers, oncogene, growth faktor, cytokine, dan kemoterapi diduga ikut berperan dalam ekspresi dari COX-2. ${ }^{9}$ Ekspresi COX-2 berhubungan dengan penghambatan apoptosis, peningkatan potensi metastase, dan peningkatan neoangiogenesis, atau dengan kata lain ekspresinya berhubungan dengan agresifitas dan outcome klinik yang buruk dari suatu tumor. ${ }^{10}$

Ekspresi COX-2 pada CRC dapat dipakai sebagai faktor prediktif kemampuan CRC melakukan metastase dan terjadinya rekurensi dari CRC. ${ }^{11}$ Ekspresi COX-2 intratumoral dapat sebagai faktor prediktif terhadap respon kemoterapi dan juga faktor prognostik terhadap survival pasien setelah kemoterapi. ${ }^{12}$

Di Indonesia umumnya dan di Bali khususnya, diagnosis CRC masih berdasarkan atas faktor konvensional berupa gambaran klinis dan patologis seperti umur, gejala klinis, tipe histopatologis, derajat diferensiasi tumor, stadium tumor baik berupa Dukes' Staging System maupun TNM (tumor-nodulmetastase) sistem dari American Joint Committee on Cancer (AJCC). Terapi CRC pun masih berdasarkan prosedur baku seperti pembedahan radikal, kemoterapi serta radioterapi sebagai terapi ajuvan. Saat ini belum banyak dikembangkan targetted therapy pada CRC di Indonesia, penggunaannya masih terbatas pada penelitian penelitian yang sedang berjalan. Sampai saat ini diagnosis dan terapi CRC belum melibatkan penanda molekuler seperti onkogen (K-ras), COX-2, tumor suppresor gen (APC, p53), growth factor (VEGF dan FGF), faktor antiapoptotik (Bc12), dan faktor imunomodulasi (CTLs, TIL). Di Amerika, diagnosis dan terapi CRC telah melibatkan banyak penanda molekuler tersebut dan terbukti lebih cost 
effective dibandingkan diagnosis dan terapi tanpa penanda molekuler. ${ }^{13}$

Parameter-parameter konvensional berupa gambaran klinis dan patologis belum cukup untuk memprediksi rekurensi, progresifitas, prognosis dan keberhasilan terapi CRC, diperlukan penggunaan penanda molekuler untuk menilai perubahan yang terjadi di level seluler yang berperan dalam CRC. Penanda seluler yang dipilih pada penelitian ini adalah COX-2, berdasarkan peranannya dalam karsinogenesis CRC.

\section{METODE}

Penelitian ini merupakan suatu analytics cross sectional study yang dilakukan di Bagian Ilmu Bedah dan di Bagian Patologi Anatomi FK UNUD/RS Sanglah Denpasar serta Bagian Patologi Anatomi FK UGM/RS Dr. Sardjito, Yogyakarta. Dengan sampel penelitian meliputi semua penderita CRC yang dirawat di Bagian Bedah FK UNUD/RS Sanglah, mulai periode September 2004 sampai November 2005, dengan berbagai stadium yang sudah dibuktikan secara histopatologis melalui biopsi jaringan. Gambaran klinikopatologis penderita yang di analisa berupa jenis kelamin, umur, lokasi tumor, tipe histopatologis, derajat differensiasi dan stadium TNM

Ekspresi COX-2 merupakan gambaran ekspresi COX-2 yang dapat dilihat dengan menggunakan pemeriksaan imunohistokimia. Dengan mikroskop pada pembesaran 400 kali, pada 10 lapangan pandang. Ekspresi COX-2 dicatat dengan sistem skoring semikuantitatif, dengan cut off point 100 dan mean score yang digunakan untuk analisis statistik adalah $+2 .{ }^{14}$ Sehingga hasil scanning dari pemeriksaan imunohistokimia didapatkan berupa: ekspresi 0 atau negatif: 0-99, ekspresi +1 atau low expression: 100-159, ekspresi + 2 atau moderate expression: 160219 , ekspresi +3 atau strong expression: lebih dari 220. Untuk analisis statistik ditetapkan: lack expression berupa 0 dan +1 serta over expression berupa +2 dan +3 .

Selama periode September 2004 sampai November 2005, tercatat 71 penderita CRC yang dilakukan tindakan pembedahan baik kolostomi-biopsi, reseksi kolon sampai pada abdominoperineal approach (Miles procedure operation). Dari 71 kasus, 1 penderita tidak diikutsertakan karena telah mendapatkan kemoterapi sebelumnya, 17 penderita tidak diikutsertakan karena catatan medis tidak lengkap, data klinikopatologis tidak ada atau tidak lengkap. Terdapat 4 penderita dengan TBC usus, MALT (mucosa associated lymphoid tissue) lymphoma dan kista epidermoid. Dari 49 penderita yang tersisa, 3 penderita tidak ditemukan parafin blok sebagai spesimen penelitian imunohistokimianya dan tidak dapat diperiksa imunohistokimianya. Sehingga dari 71 penderita tersebut, secara keseluruhan 25 penderita dieksklusi dari penelitian ini dan hanya 46 penderita yang layak diikutkan pada penelitian ini.

\section{HASIL}

Terdapat COX-2 terekspresi pada 42 kasus $(91,3 \%)$ dari 46 kasus, 4 kasus $(8,7 \%)$ terekspresi negatif. Ekspresi COX-2 dikatagorikan +1 pada 16 kasus $(34,8 \%)$, +2 pada 17 kasus $(36,9 \%)$ dan +3 pada 9 kasus $(19,6 \%)$. Dari 46 penderita tersebut, 34 penderita $(73,9 \%)$ laki-laki, sedang sisanya 12 penderita $(26,1 \%)$ perempuan. Rata-rata penderita berusia 51,15 tahun dengan standar deviasi 15,089 tahun. Rentang usia dari 22 tahun yang termuda sampai 86 tahun yang tertua. Setelah dilakukan recode dengan SPSS 11.5, 
terdapat $19(41,3 \%)$ penderita berumur kurang dari 50 tahun atau dikatakan muda dan $27(58,7 \%)$ penderita berumur $\geq 50$ tahun atau dikatakan tua.

Berdasarkan lokasi tumornya, dari 46 penderita tersebut, 2 penderita tumor terdapat pada saekum, 4 penderita pada kolon asenden, 2 penderita pada kolon desenden, 13 penderita pada kolon sigmoid dan sisanya 25 penderita pada rektum. Setelah dilakukan recode menggunakan SPSS 11.5, terdapat $21(45,7 \%)$ penderita dengan kanker kolon dan 25 (54,3\%) penderita kanker rektum. Selengkapnya hasil Ekspresi COX-2 dan gambaran klinikopatologis CRC tercantum dalam tabel 1.

Tabel 1. Hubungan ekspresi COX-2 dan gambaran klinikopatologis CRC

\begin{tabular}{|c|c|c|c|c|c|c|}
\hline \multirow{2}{*}{$\begin{array}{c}\text { Gambaran } \\
\text { Klinikopatologis CRC }\end{array}$} & \multicolumn{4}{|c|}{ Ekspresi COX-2 } & \multirow{2}{*}{$\begin{array}{l}\text { Spearman' } \\
\text { s rho }\end{array}$} & \multirow{2}{*}{$\begin{array}{l}\text { Nilai } \\
\text { p }\end{array}$} \\
\hline & $\mathbf{0}$ & +1 & +2 & +3 & & \\
\hline Umur & & & & & 0,066 & 0,664 \\
\hline \multicolumn{7}{|l|}{ Muda (<50 tahun) } \\
\hline \multicolumn{7}{|l|}{ Tua ( $\geq 50$ tahun) } \\
\hline Lokasi tumor & & & & & 0,188 & 0,212 \\
\hline \multicolumn{7}{|l|}{ Kolon } \\
\hline \multicolumn{7}{|l|}{ Rektum } \\
\hline Tipe Histopatologis & & & & & 0,045 & 0,766 \\
\hline \multirow[t]{2}{*}{ Adenocarcinoma } & 3 & 11 & 13 & 5 & & \\
\hline & $(9,4 \%)$ & $(34,3 \%)$ & $(40,7 \%)$ & $(15,6 \%)$ & & \\
\hline Adenocarcinoma & 1 & 5 & 3 & 2 & & \\
\hline Mucinous & $(9,1 \%)$ & $(45,4 \%)$ & $(27,3 \%)$ & $(18,2 \%)$ & & \\
\hline \multirow[t]{2}{*}{ Signet Ring Cell } & & & 1 & 2 & & \\
\hline & & & $(33,3 \%)$ & $(66,6 \%)$ & & \\
\hline Derajat differensiasi & & & & & 0,456 & 0,001 \\
\hline \multirow[t]{2}{*}{ Well } & 1 & 6 & 2 & & & \\
\hline & $(11,1 \%)$ & $(66,6 \%)$ & $(22,2 \%)$ & & & \\
\hline \multirow[t]{2}{*}{ Moderate } & 3 & 10 & 14 & 3 & & \\
\hline & $(10 \%)$ & $(33,3 \%)$ & $(46,6 \%)$ & $(10 \%)$ & & \\
\hline \multirow[t]{2}{*}{ Poorly } & & & 1 & 6 & & \\
\hline & & & $(14,3 \%)$ & $(85,7 \%)$ & & \\
\hline Stadium TNM & & & & & 0,846 & 0,000 \\
\hline \multirow[t]{2}{*}{ Stadium I } & 4 & 9 & & & & \\
\hline & $(30,8 \%)$ & $(69,2 \%)$ & & & & \\
\hline \multirow[t]{2}{*}{ Stadium II } & & 6 & 2 & & & \\
\hline & & $(75 \%)$ & $(25 \%)$ & & & \\
\hline \multirow[t]{2}{*}{ Stadium III } & & 1 & 15 & 3 & & \\
\hline & & $(5,3)$ & $(78,9 \%)$ & $(15,7 \%)$ & & \\
\hline \multirow[t]{2}{*}{ Stadium IV } & & & & 6 & & \\
\hline & & & & $(100 \%)$ & & \\
\hline
\end{tabular}




\section{DISKUSI}

Dari 71 kasus CRC dalam periode penelitian, 25 penderita tidak diikutsertakan karena tidak memenuhi kriteria sampel, dan 17 penderita $(68 \%)$ yang dieksklusi karena catatan medis tidak lengkap dan data klinikopatologis tidak ada atau tidak lengkap. Diperlukan pencatatan yang lebih detail dan lengkap terutama stadium klinis penderita CRC, hal ini sangat diperlukan karena stadium klinis terutama TNM sangat berperan dalam menentukan prognosis dan survival penderita CRC serta kemungkinan kekambuhannya. Gunderson, et al menyebutkan peningkatan stadium $\mathrm{T}$ pada TNM sistem tidak menyebabkan perubahan yang berarti pada angka ketahanan hidup maupun kekambuhannya ${ }^{15}$, tetapi sebaliknya peningkatan stadium $\mathrm{N}$ pada TNM sistem menyebabkan penurunan yang signifikan overall survival (OS) dan dissease free survival (DFS), serta peningkatan yang signifikan dari kekambuhan dan metastasenya. Hal ini menyokong tindakan total mesorectal excision sebagai standar tindakan pada kanker rektum ${ }^{16}$, dan diseksi kelenjar limfe regional pada kanker kolon, karena jumlah kelenjar limfe yang didiseksi dan dianalisis merupakan faktor prognostik untuk outcome CRC. ${ }^{17,18}$

Ekspresi COX-2 biasanya terjadi pada tahap awal dari karsinogenesis CRC yaitu pada tahap inisiasi yang membentuk early adenoma, dan terus terekspresi dan ekspresinya meningkat seiring karsinogenesis. ${ }^{19}$ Ekspresi COX-2 dapat ditemukan pada jaringan maligna dan premaligna dari tumor epitelial maupun non epitelial. Pada jaringan maligna, terjadi peningkatan ekspresi COX-2 bila dibandingkan dengan jaringan yang non maligna. ${ }^{20}$ Ekspresi COX-2 meningkat secara dramatis pada jaringan yang mengalami keganasan bila dibandingkan dengan mukosa normal. Pada jaringan kolorektal, COX-2 terekspresi pada 50\% adenoma dan pada $85 \%$ jaringan karsinoma. $^{4}$ Penelitian lain, COX-2 terekspresi pada $72 \%$ adenoma, $84,7 \%$ tumor primer dan terekspresi pada $100 \%$ CRC yang telah metastase. ${ }^{21}$

Cancer statistics yang dilaporkan pada tahun 2003 yang menyebutkan perbandingan laki-laki sebanding dengan perempuan. $\mathrm{Wu}$, et al juga menyebutkan insiden pada laki laki sebanding dengan pada perempuan, dan tidak ada hubungan yang signifikan antara jenis kelamin dan ekspresi COX-2. ${ }^{1,14}$

Pada tahun 2005, Hawk dan Levin mengemukakan bahwa insiden tertinggi pada dekade ke-5 atau umur 50 tahun. Dalam hubungannya dengan deteksi dini CRC, maka deteksi dini dimulai pada umur 30-40 tahun, karena pembentukkan CRC dari sel kolorektal normal memerlukan waktu 10-20 tahun. $^{22}$ Setelah dilakukan recode dengan cut off point 50 tahun, menjadi CRC usia muda dan CRC usia tua tidak ditemukan hubungan yang signifikan antara usia penderita dengan ekspresi COX2. Zhang dan $\mathrm{Wu}$ juga tidak menemukan hubungan yang signifikan antara umur dan ekspresi COX-2. ${ }^{14,21}$

Vogelstein menyebutkan secara klasik CRC dibagi menjadi familial cancers syndrome (FAP dan HNPCC), berkisar antara 5-15\% dari keseluruhan insiden dan terjadi pada umur yang lebih muda, sedangkan sebagian besar sisanya merupakan nonhereditary atau sporadic cancers. ${ }^{5}$ Nagorni menyebutkan bahwa FAP menyebabkan timbulnya ratusan adenoma pada usia 16 tahun dan akan terbentuk CRC pada usia 25-30 tahun. ${ }^{23}$ 
Pada penelitian ini juga ditemukan satu kasus dengan poliposus multipel kolon pada laki-laki usia 15 tahun, tetapi penderita tersebut dieksklusi karena tidak dapat dilakukan pemeriksaan imunohistokimia. Penelitian ini tidak dapat membedakan penderita mengalami familial cancers syndrome atau sporadic cancers.

Pada penelitian ini insiden kanker kolon sebanding dengan kanker rektum, berbeda dengan cancer statistics pada tahun 2003 yang menyebutkan perbandingan kanker kolon dan kanker rektum 2 berbanding 1 . Hal ini dimungkinkan karena penggunaan modalitas diagnostik dalam deteksi dini CRC seperti flexible sigmoidoscopy dan kolonoskopi. $^{22}$ Setelah dilakukan uji korelasi lokasi tumor dan ekspresi COX-2 tidak didapatkan korelasi yang signifikan diantara keduanya, berbeda dengan penelitian Dimberg, et al yang menyebutkan ekspresi COX-2 pada kanker rektum lebih tinggi secara signifikan dibandingkan kanker kolon. ${ }^{24}$ Hal sejenis dikemukakan Einspahr, bahwa ekspresi COX-2 lebih tinggi secara signifikan pada adenoma yang lebih distal, COX-2 inhibitor lebih sensitif terhadap adenoma pada rektosigmoid dibandingkan dengan lokasi lainnya. ${ }^{25}$

Pada penelitian ini, 43 penderita $(93,4 \%)$ dari 46 sampel penelitian dengan adenocarcinoma. Hal ini sesuai dengan distribusi yang dikemukakan Rousseau dalam MD Anderson Surgical Oncology Handbook bahwa 90\% CRC merupakan adenocarcinoma, tipe histopatologi lainnya meliputi adenosquamous carcinoma, signet ring cell, carcinoid dan leiomyosarcoma. ${ }^{26}$ Penelitian ini tidak menemukan hubungan yang signifikan antara tipe histologis dan ekspresi COX-2, tetapi dari data didapatkan 3 penderita dengan signet ring cell, seluruhnya dengan poorly differentiated dan ditemukan pada stadium lanjut (stadium III dan IV) serta seluruhnya mengalami over expression $\mathrm{COX}-2$. Wu, et al, tidak menemukan hubungan yang signifikan antara ekspresi COX-2 dengan type histopatologi CRC. ${ }^{14}$

Sato, et al mengemukakan bahwa dengan pemeriksaan immunohistokimia ekspresi COX-2 berhubungan dengan derajat differensiasi dan aktifitas proliferasi dari CRC, dan dalam kesimpulan penelitiannya menyebutkan bahwa peningkatan ekspresi COX-2 berhubungan dengan pertumbuhan dan transformasi maligna dari suatu adenoma dan memegang peranan penting dalam progresi dari CRC. ${ }^{27}$ CRC dengan over ekspresi COX-2 merupakan target terapi potensial dengan COX-2 inhibitor. Sebaliknya Einspahr, et al. menyimpulkan berdasarkan penelitiannya bahwa ekspresi COX-2 tidak berhubungan dengan derajat differensiasi CRC. ${ }^{25}$

Zhang menyebutkan bahwa COX-2 terekspresi pada $72 \%$ adenoma dan terekspresi pada seluruh (100\%) CRC yang telah metastase dan ekspresi COX-2 berhubungan dengan stadium Dukes dari CRC. ${ }^{21} \mathrm{Wu}$, et al mengemukakan bahwa COX-2 tidak terekspresi atau terekspresi lemah pada sel kolorektal normal dan adenoma, dan terekpresi kuat atau over expression pada lebih dari 84\% CRC stadium II, III, dan IV, tetapi hubungan ekspresi COX-2 dan stadium TNM secara statistik tidak signifikan. ${ }^{14}$ Pada bagian lain dari penelitiannya memperlihatkan bahwa ekspresi COX-2 meningkat sesuai kedalaman invasi tumor tersebut yaitu COX-2 terekspresi pada $80 \%$ kasus bila invasi sampai submukosa, $82,8 \%$ bila invasi sampai muskularis, $85 \%$ bila invasi sampai serosa dan $86,4 \%$ bila invasi sampai jaringan sekitar, tetapi hubungan ekspresi 
COX-2 dengan kedalaman invasi secara statistik juga tidak signifikan. Ekspresi COX-2 lebih tinggi secara signifikan pada CRC yang mempunyai ukuran besar dan invasi yang lebih dalam. ${ }^{28}$ Pada penelitian yang lain dilaporkan ekspresi COX-2 meningkat pada sporadik CRC terutama yang berdiameter besar. ${ }^{29,30}$

Setelah dilakukan uji korelasi antara derajat differensiasi dan stadium TNM ternyata didapatkan keduanya berhubungan secara signifikan. Zhang menyebutkan bahwa COX-2 tidak terekspresi pada jaringan normal, terekspresi sedang pada adenoma dan terekspresi kuat pada CRC bahkan sangat kuat pada CRC yang telah metastase. Espressi COX-2 lebih tinggi secara signifikan pada sel yang mengalami displasia dan pada sel yang mengalami proliferasi ${ }^{21}$. Tomozawa, et al dalam penelitiannya menyebutkan bahwa penderita CRC dengan overekspresi COX2 menunjukkan angka metastasis secara hematogen yang lebih tinggi ${ }^{31}$.

Tomozawa, et al menyebutkan ekspresi COX-2 merupakan satu-satunya faktor prognostik yang signifikan disamping stadium TNM dari AJCC. ${ }^{31}$ Penemuanpenemuan tersebut mendukung pentingnya peranan COX-2 pada pertumbuhan CRC, tetapi kemampuan invasi suatu tumor, kemampuan tumor untuk metastasis dan derajat differensiasi merupakan suatu proses yang kompleks yang melibatkan gen yang multipel, sehingga peranan hanya satu gen dalam proses tersebut harus dievaluasi secara hati-hati. ${ }^{14}$

\section{SIMPULAN}

Ekspresi COX-2 berhubungan dengan differensiasi sel yang buruk (poorly differentiated) serta berhubungan dengan stadium klinik yang lanjut (stadium III dan IV). Ekspresi COX-2 tidak berhubungan dengan umur, jenis kelamin, lokasi tumor, dan tipe histopatologis CRC.

Penelitian ini mendukung pentingnya peranan COX-2 dalam karsinogenesis CRC, tetapi kemampuan invasi suatu tumor, kemampuan tumor untuk metastasis, dan derajat differensiasi merupakan suatu proses yang kompleks yang melibatkan gen yang multipel, sehingga peranan hanya COX-2 dalam proses tersebut harus dievaluasi secara hati-hati.

\section{DAFTAR PUSTAKA}

1. Mahmoud N, Rombeau J, Ross HM, et al. Neoplasia of Colon and Rectum. In: Townsend CM, Beauchamp RD, Evers BM, et al., editors, Sabiston Textbook of Surgery, The Biological Basic of Modern Surgical Practice. 17th. Ed. Philadelphia: Elsevier; 2004.p.1443-62.

2. Meyerhardt JA, Mayer RJ. Systemic Therapy for Colorectal Cancer. $N$ Engl J Med. 2005;352:476-87.

3. Thierry A, Boni C, Mounedji-Boudiaf L, et al. Oxaliplatin, Fluorouracil, and Leucovorin as Adjuvant Treatment for Colon Cancer. $N$ Engl $J$ Med. 2004;350:2343-51.

4. Brown, JR, DuBois RN. COX-2: A Molecular Target for Colorectal Cancer Prevention; J Clin Oncol. 2005;23:2840-55.

5. Vogelstein B, Kinzler KW. The multistep nature of cancer. Trends Genetic. 1993;9:138-41.

6. Boedefeld WM, Bland KI, Heslin MJ. Recent Insights Into Angiogenesis, Apoptosis, Invasion, and Metastasis in Colorectal Carcinoma. Annals Surg Oncol. 2003;10:839-51.

7. Berger G, Benjamin LE. Tumorigenesis and the Angiogenic Switch. Nature Reviews. 2003;3:401-10. 
8. Elstrom RL, Thompson CB. Cell Life and Cell Death. In: Abeloff MD, Armitage JO, Niederhuber JE, et al., editors. Clinical Oncology. 3rd. Ed. London: Churchill Livingstone; 2004.p.101-12.

9. DuBois RN, Martin E, Arnold M, et al. Cyclooxygenase in Biology and Disease. The FASEB J. 1998;12:106373.

10. Ferrandina G, Lauriola L, Zannoni GF, et al. Expression of cyclooxygenase-2 (COX-2) in tumour and stroma compartments in cancer: clinical implications. $\mathrm{Br} J \quad$ Cancer. 2002;87:1145-52.

11. Garcea G, Sharma RA, Denisson A, et al. Molecular biomarkers of colorectal carcinogenesis and their role in surveillance and early intervention. Eur J Cancer. 2003;39:1041-52.

12. Uchida K, Schneider S, Yochim JM, et al. Intratumoral COX-2 Gene Expression is a Predictive Factor for Colorectal Cancer Response to Fluoropyrimidine-Based

Chemotherapy. Clin Cancer Res. 2005;11:3363-68.

13. Keller J, Giardello F. Chemopreventive Strategies Using NSAIDs and COX-2 Inhibitors. Cancer Control. 2003;2:140-9.

14. $\mathrm{Wu} \mathrm{AW}, \mathrm{Gu}$ J, Ji JF, et al. Role of COX-2 in Carcinogenesis of Colorectal Cancer and its Relationship with Tumor Biological Characteristics and Patients' Prognosis. World J Gastroenterol. 2003;9:1990-4.

15. Gunderson LL, Sargent DJ, Tepper JE, et al. Impact of $\mathrm{T}$ and $\mathrm{N}$ Stage and treatment on Survival and Relapse in Adjuvant Rectal Cancer. J Clin Oncol. 2004;22:1785-96.
16. Brennan TV, Lipshutz GS, Gibbs VC, et al. Total Mesenteric Excision in The Treatment of Rectal Carcinoma: Methods and Outcomes. Surgical Oncology. 2002;10:171-6.

17. LeVoyer TE, Sigurdson EL, Hanlon AL, et al. Colon Cancer Survival Is Associated With Increasing Number of Lymph Nodes Analyzed. J Clin Oncol. 2003;21:2912-9.

18. Nelson H, Petrelli N, Charlin A, et al. Guidelines 2000 for Colon and Rectal Cancer Surgery. J National Cancer Institute. 2001;93:583-96.

19. Aust DE, Terdiman JP, Willenbucher $\mathrm{RF}$, et al. The APC/ $\beta$-Catenin Pathway in Ulcerative Colitis-Related Colorectal Carcinomas. Cancer. 2002;94:1421-7.

20. Wheeler JMD, Warren BF, Mortensen NJ, et al. An insight into the genetic pathway of adenocarcinoma of the small intestine. Gut. 2002;50:218-23.

21. Zhang H, Sun XF. Overexpression of Cyclooxygenase-2 Correlates with Advanced Stages of Colorectal Cancer. Am J Gastroenterol. 2002;9:1990-4.

22. Hawk ET, Levin B. Colorectal Cancer Prevention. J Clin Oncol. 2005;23:37891.

23. Nagorni A. Genetics of Colorectal Cancer. Medicine and Biology. 2002;9:142-9.

24. Dimberg J, Samuelson A, Hugander A, et al. Differential Expression of Cyclooxygenase-2 in Human Colorectal Cancer. Gut. 1999;45:730-2.

25. Einspahr JG, Krouse RS, Yochim JM, et al. Association Between Cyclooxygenase Expression and Colorectal Adenoma Characteristics. Cancer Res. 2003;63:3891-3.

26. Rousseau DL, Midis GP, Feigh BW. Cancer of Colon, Rectum and Anus. In: Feigh, BW, editor. MD Anderson 
Surgical Oncology Handbook. 3rd. Ed. Philadelphia: Lippincott Williams \& Wilkins; 2003.p.215-65.

27. Sato $\mathrm{T}$, Yoshinaga $\mathrm{K}$, Okabe $\mathrm{S}$, et al. Cyclooxygenase-2 Expression and its Relationship with Proliferation Colorectal Adenomas. Jpn J Clin Oncol. 2003;33:631-5.

28. Fujita T, Takaku K, Matsui M, et al. Size and Invasion Dependent Increase in Cyclooxygenase-2 Levels in Human Colorectal Carcinoma. Cancer Res. 1998;58:4823-6.

29. Elder DJ, Baker JA, Banu NA, et al. Human Colorectal Adenomas Demonstrate a Size-Dependent Increase in Epithelial Cyclooxygenase2 Expression. J Pathol. 2002;198:42834.

30. Hasegawa K, Ichikawa W, Fujita T, et al. Expression of Cyclooxygenase-2 (COX-2) mRNA in Human Colorectal Adenomas. Eur $J$ Cancer. 2001;37:1469-74.

31. Tomozawa $\mathrm{S}$, Tsuno NH, Sunami E, et al. Cyclooxygenase-2 Overexpression Correlates with Tumour Recurrence, Especially Haematogenous Metastasis, of Colorectal Cancer. Brit J Cancer. 2000;83:324-8 